\title{
Dictynna
}

Dictynna

Revue de poétique latine

17 | 2020

International Ovidian Society en Europe I

\section{Trapped between Scylla and Ciris: Some Thoughts on Poetic Structure}

Laurel Fulkerson

\section{(2) OpenEdition \\ 1 Journals}

\section{Electronic version}

URL: https://journals.openedition.org/dictynna/2167

DOI: 10.4000/dictynna.2167

ISSN: 1765-3142

\section{Publisher}

Université de Lille

\section{Electronic reference}

Laurel Fulkerson, "Trapped between Scylla and Ciris: Some Thoughts on Poetic Structure", Dictynna [Online], 17 | 2020, Online since 17 December 2020, connection on 17 December 2022. URL: http:// journals.openedition.org/dictynna/2167 ; DOI: https://doi.org/10.4000/dictynna.2167

This text was automatically generated on 17 December 2022.

\section{(c) (i) (9)}

Creative Commons - Attribution-NonCommercial-NoDerivatives 4.0 International - CC BY-NC-ND 4.0 https://creativecommons.org/licenses/by-nc-nd/4.0/ 


\title{
Trapped between Scylla and Ciris: Some Thoughts on Poetic Structure ${ }^{1}$
}

\author{
Laurel Fulkerson
}

1 This chapter focuses on the pseudo-Vergilian Ciris and Ovid's Scylla-episode in book 8 of the Metamorphoses, suggesting that, although their relationship has been very wellexplored, it has not been especially well-understood. In general, the main question asked about these two episodes is a chronological one ("who stole from whom?"); my aims here are rather different. The two narratives, broadly similar, tell the story of the daughter of the Megaran king who, while her city is being besieged by the Cretans, falls in love with their leader, Minos. Luckily for her - but unluckily for Megara - her father Nisus has a crimson lock of hair which, so long as it remains attached to his head, guarantees that the kingdom cannot be taken. Scylla shears the lock and offers it and herself to Minos who, outraged, rejects her. She jumps into the water after his departing ship and is turned into the ciris (a sea-bird of some kind). Her father is turned into a sea-eagle (the haliaeeutes) and pursues her, seemingly without end.

2 As I have noted, much of the comparative scholarship on these episodes focuses on Prioritätsbestimmung. And, although conclusions about such matters tend to be drawn with confidence, the majority of them remain unconvincing, not least because they disagree about the criteria to be used in determining priority. ${ }^{2}$ Instead of revisiting questions of relative chronology, then, I hope in this chapter to offer a novel treatment of Ovidian intertextuality vis à vis pseudepigraphic poetry. More specifically, I will be exploring the mutually reinforcing gaps in our two Scylla-narratives, the places where one poet does not treat a portion of the story prominently featured in the other. These gaps in content are notable, and, in fact, they might even seem to suggest that each poet has omitted the portions of the narrative that feature in the other's version. Structural features like these are usually taken as clues to which author is derivative, but I want instead to examine them from a reader's perspective to see what they can tell us about differences in style or genre (and perhaps intent, though that is not my main focus). For it turns out that each poem leaves out key elements of the story, such that it looks as though both authors may be composing with an eye to each other (my 
stronger, not-fully-substantiable claim), or at least that priority is not the only significant factor in their relative compositional choices (my weaker and lesscontroversial claim). Either way, my hope is to decentralize questions of authorship and dating and to explore instead what we find when we read the scenes together.

One of our Scylla-stories is an episode set into a larger narrative that has sometimes been seen as a series of epyllia strung together, ${ }^{3}$ the other is a self-standing work that we might for the sake of convenience call neoteric epyllion. ${ }^{4}$ The Metamorphoses, however, is significantly more complicated as a work than the Ciris, and I suggest that the complex structure of the Metamorphoses, specifically its incorporation of a wide array of tales, accounts for the majority of the differences between the two stories.

4 First, because it is not as well-known as Ovid's Metamorphoses, I offer a little background information about the pseudo-Vergilian Ciris. This 541-line hexameter poem, dedicated to Messalla, comes to us as part of the Appendix Vergiliana, a group of texts attached to the name of Vergil under various circumstances and at various times; the general scholarly consensus is that none of the poems was written by Vergil, although some of them, including this one, explicitly or implicitly claim Vergilian authorship; Donatus' Vita Vergilianae attributes the poem to a young Vergil, which may mean that Suetonius did too. The Ciris has been argued to be by Ovid. It has also been argued to be by Vergil, by Gallus, and by any number of other famous and not-so-famous poets, as well as by anonymous first-, second- or even third-century CE authors. ${ }^{5}$ Some of the confusion in dating the poem can be traced to the fact that different critics apply different criteria to it. And, as is often the case in studies of pseudepigraphic or anonymous poetry, the question of dating is inextricably tied to opinions about the quality of the poem: the later the text, the worse it is assumed to be, and the less a critic finds merit in it, the later it seems likely to be.

5 I want today to take a different approach, focusing instead on some of the structural issues within the myth itself, namely, which components of the story appear in which version of it and (perhaps) why. There seems to be a tacit assumption on the part of critics, perhaps by analogy to Terence's alleged contaminatio of Greek comic plots, that a later poet must or should compress or omit scenes treated by his predecessor, and that he has the consequent freedom to expand upon or create elements or scenes not already "used up". Indeed, this is not an unreasonable starting point: it is a practice followed by many poets much of the time, and is further a feature of Ovid's poetic composition vis à vis, for instance, Vergil. ${ }^{6}$ Among many examples, consider the tale of Orpheus and Eurydice in Georgics 4 and in Metamorphoses 10, with the first, I would argue, deliberately omitting Orpheus' miraculous song and the second just as deliberately including it. Further, to whatever degree authors are constrained by their predecessors' choices, their own decisions about what pieces of a story to narrate and what to omit, naturally create rather different narrative effects.

6 It is, however, important to note that myths only ever exist in particular renderings of them, be they textual or visual, and so this identification of "key" or "original" elements in them can really only be done with reference to a specific predecessor: we will never find the "true" myth that pre-exists its versions. Yet the history of criticism of the Ciris is full of attempts to date it relative to other poems based on how often it goes "off-script" from the "real/original" tale (= the one written by an earlier and better poet). Such studies are inevitably subjective, and often come to widely differing conclusions about which aspects are central or even necessary to a particular tale. 
7 And indeed, matters are always immeasurably complicated by the fact that we have but a small fraction of the poetry written in Latin and in Greek, so we rarely know whether there was a previous treatment of a given story or - where we do have a predecessor the details of the various variant versions. In the case of Scylla, two preceding but nolonger-extant treatments of the myth are surely influential on our poets in ways we cannot now determine, Callimachus' Hecale fr. 288/90 Hollis and Parthenius Metamorphoses 24a Lightfoot. ${ }^{7}$

8 So too, mythology tends to repeat themes across tales, which further complicates any attempt to establish a relative chronology or determine "original" elements. In what follows, I shall refer to "mythic doublets" or "similar tales" to Scylla's, and by that I mean, in different contexts, the stories of Myrrha, Ariadne, Medea, Byblis, Tarpeia, and even Hypermestra and Canace, all women who fall in love with the wrong man, and most of whom also betray either their fathers or their cities or both. ${ }^{8}$

I offer a single relevant example of the kind of issue that obtrudes when we compare two versions of a plot in search of its "essence": must a woman about to do something dreadful engage in a so-called "tragic" monologue? If she instead has a dialogue with a co-conspirator, must we conclude that "her" monologue has already been written by someone else, and so has been "used up"? If there is a monologue in a different place in the narrative, must we also therefore assume that the poet, knowing a monologue is appropriate but not allowed to have one, is thereby trying to make up for his belatedness?

10 As an experiment in moving beyond chronology to questions of poetic composition from a readerly perspective, this chapter expands upon the structure of the two versions of the Scylla narrative, which I include in parallel here: ${ }^{9}$

\begin{tabular}{|l|l|}
\hline Ov. Met. 8.1-151: Scylla & [Verg.] Ciris (541 lines) \\
\hline & $\begin{array}{l}1-53 \quad \text { introduction: poet's aspirations, Epicureanism, } \\
\text { Messalla, Panathenaic procession; this poem a first/youthful } \\
\text { effort, about Scylla }\end{array}$ \\
\hline $\begin{array}{l}\text { 1-22 transition and description of Nisus } \\
\text { and Megara, at war with Minos; tower on } \\
\text { the walls and allusion to Apollo's lyre; } \\
\text { Scylla's teichoskopeia }\end{array}$ & $\begin{array}{l}54-91 \text { metapoetic interlude: alternate versions of tale, other } \\
\text { Scyllae }\end{array}$ \\
\hline $\begin{array}{l}\text { 23-43 Scylla's infatuation; description of magic hair } \\
\text { Minos }\end{array}$ & $\begin{array}{l}\text { 129-90 Ciris' infatuation and its possible causes (including } \\
\text { whether she is to blame or not); description of her madness; } \\
\text { mention of towers and her observation of enemy camp }\end{array}$ \\
\hline & $\begin{array}{l}\text { 191-205 address to Nisus and foreshadowing of } \\
\text { metamorphoses }\end{array}$ \\
\hline
\end{tabular}




\begin{tabular}{|c|c|}
\hline \multicolumn{2}{|l|}{$\begin{array}{l}\text { 44-80 Scylla's monologue about her own } \\
\text { treachery; decision to cut lock of hair }\end{array}$} \\
\hline & 206-19 darkness, Ciris' (failed) attempt to cut lock \\
\hline & $\begin{array}{l}220-256 \text { interruption by Carme's monologue (mostly about } \\
\text { incest); they go inside }\end{array}$ \\
\hline & $\begin{array}{l}\text { 257-282 Ciris' monologue and confession; display of knife, } \\
\text { to dubious purpose }\end{array}$ \\
\hline & $\begin{array}{l}\text { 283-348 Carme's diatribe against Minos, including his } \\
\text { relationship to Britomartis;_Carme suggests alternatives to } \\
\text { cutting lock; Ciris sleeps while Carme watches }\end{array}$ \\
\hline & $\begin{array}{l}\text { 349-385 Ciris talks to her father about marriage and } \\
\text { religious omens; Carme tries magic; the two women decide } \\
\text { to cut the lock }\end{array}$ \\
\hline $\begin{array}{l}\text { 81-89 darkness; cutting of lock, journey to } \\
\text { Minos }\end{array}$ & $\begin{array}{l}\text { 386-403 cutting of lock; war is over; Ciris dragged } \\
\text { along hanging from ship as nymphs marvel }\end{array}$ \\
\hline $\begin{array}{l}90-100 \text { Scylla's address to Minos and his } \\
\text { rebuff }\end{array}$ & \\
\hline [war is over] & \\
\hline 101-7 Minos plans to depart; Scylla prays & \\
\hline $\begin{array}{l}\text { 108-42 Scylla's second monologue, } \\
\text { berating Minos for his cruelty and } \\
\text { savagery while he departs }\end{array}$ & $\begin{array}{l}404-58 \text { Ciris' second monologue, addressed to birds, } \\
\text { berating but not blaming Minos }\end{array}$ \\
\hline $\begin{array}{l}\text { 143-51 Scylla chases ship; father, now an } \\
\text { osprey, attacks her. She falls and turns } \\
\text { into the ciris }\end{array}$ & $\begin{array}{l}\text { 459-519 Ciris' travelogue; sea-monsters; Amphitrite turns } \\
\text { her into a beautiful bird (metamorphosis described at some } \\
\text { length); bird flies away to live alone }\end{array}$ \\
\hline & $\begin{array}{l}\text { 520-41 Jupiter thinks this is not sufficient punishment, so } \\
\text { turns Nisus into a sea-eagle, who chases her forever }\end{array}$ \\
\hline
\end{tabular}

Fig. 1: Scylla vs. Ciris: italics used to denote elements unique to one version

11 In the hopes of keeping things simple, I shall henceforth denote the Ovidian version of this myth the "Scylla" tale, and the pseudo-Vergilian the "Ciris" tale, and I'll name the two women involved in the same way. The tale of Scylla (i.e., Ovid's version in the Metamorphoses) lasts about 150 lines, while the tale of Ciris (in the pseudo-Vergilian Ciris) is more than three times as long. The Ciris is full of what we might, in an ungenerous mood, consider digressions; less disparagingly, we might say that it contains several inset narratives and encapsulated allusions to other myths. 
12 What belongs and what does not, as we have already noted, is subjective: my own opinion is that the one-hundred line metapoetic prologue to the Ciris is the only part of the poem we can be confident is unrelated to the main story, for the simple reason that it does not tell that story..$^{10}$ And their relative lengths may tell us something about the chronology of the two poems, but then again they may not: if one story were chronologically dependent upon the other, we might expect the later poet (Ovid, say) to feel comfortable abbreviating, since the story had already been told in some detail. On the other hand, a poet might well feel compelled to add new and interesting features to make it worth the reading, as pseudo-Vergil (perhaps) does. So length does not necessarily help us to make any decisions about who came first. ${ }^{11}$

In any case, there are just about three times as many lines in the Ciris as in the Metamorphoses passage. Some readers of the Ciris might object to (for instance) the Britomartis passage, the magic ritual, the travelogue, and the address to Nisus as being extraneous to the matter at hand. But my main point is that the difference between their relative lengths allows the Ciris to take a more leisurely attitude toward its subject than the Metmorphoses 8 version, such that topics that might (if you were in a hurry) be considered superfluous can also be included. And indeed, this relative leisure is a key feature of neoteric poems or Latin epyllia, which regularly include at least one "inset narrative" containing instructive points of similarity and difference from the main story, very much like the Britomartis tale does. But it is only fair to note that Ovid's Metamorphoses contains several inset digressions too. Indeed, perhaps part of the reason for the relatively brief length of the Scylla-tale lies in the lengths of the Byblisnarrative in book 9 and the Myrrha-narrative in book 10 (both just over 200 lines); sometimes Ovid tells similar stories in compressed form, but - for whatever reason these three are to be given roughly equal weight.

We now look more closely at the plots of the two stories, skipping over the Ciris' prologue. Both poems situate us in Megara, with reminders of the singing walls that make it famous, the supernatural attributes of its king, and the fact that there is a war going on with Minos. And both do so in about the same number of lines (Ciris 101-28; Met. 8.1-22), though Ovid's Scylla adds a teichoskopeia and the Ciris a bit more about how the war began. Further along, we hear about the girl's infatuation with Minos with, in Ovid's Scylla (Met. 8.23-43), a description of his appearance, and in the pseudoVergilian Ciris (129-90), mention of her observation of him from the walls and a lengthy discussion about where this infatuation came from and whether it is culpable or not, along with her symptoms.

Most of these expansive elements in the Ciris can be paralleled by other similar narratives from the Metamorphoses, such that we can easily excuse their absence in Ovid's text. The one that cannot, interestingly, is what we might call the moral aspect of the question - Ciris' potential culpability - and it is one of the Ciris-poet's most significant concerns throughout the poem (including in the prologue). The evidence does not permit us to conclude whether such moral questions normally feature in Latin epyllia. What we can say is that they tend to tell stories of excessive or unusual behavior that might lend themselves to this kind of moralizing; Catullus 64 does not contain this element quite as overtly as the Ciris but it could certainly be argued that the Catullan poem contains a moral message.

16 The Ciris then provides foreshadowing (191-205), and a brief address to Nisus. The Metamorphoses, for its part, gives Scylla a "tragic" monologue which ends with her 
fateful decision (Met. 8.44-80). Scylla's speech is rhetorical, emphasising the disjunction between what is and what should be, assuring herself that she would give up anything for Minos except her homeland, and then managing to convince herself that her city is lost in any case. Scylla also blames herself for her unnecessary delay (though in fact, she is much quicker to action than her pseudo-Vergilian counterpart). This is a quintessentially Ovidian take on the tragic monologue, found throughout the Metamorphoses. ${ }^{12}$

17 But the Ciris does not eschew formally dramatic elements; it merely includes different ones in different places. Indeed, while there is little delay in Ovid between the decision and its implementation, the Ciris-poet adds nearly two hundred lines of tensionbuilding suspense (220-385). Just before these lines (206-19), Ciris heads out to do the fateful deed, but her nurse Carme interrupts, wondering what the girl can be up to. ${ }^{13}$ Carme (not Ciris) delivers a monologue (220-56) focused on the possibility of incest, which is a nice allusion, as it reminds us of Myrrha's story, which had been the main subject of Cinna's neoteric Zmyrna. ${ }^{14}$ Ciris corrects her misapprehension, launching into her own monologue about Minos and displaying the knife she is about to use to remove her father's magical lock of hair, or perhaps to commit suicide (257-82; both options seem to remain real possibilities). At the mention of the name Minos, Carme delivers another monologue-cum-lament about his pursuit of her daughter Britomartis - who jumped off a cliff to escape him and was metamorphosed into a goddess (283-348); this story may have featured in Cato's neoteric Dictynna, of which we have no fragments. Carme suggests that they try alternate means to accomplish their end, and then tucks Scylla into bed; the exhausted girl sleeps while her nurse watches over her. Nearly forty lines (349-85) and an unclear amount of time pass, during which Ciris tries by various means to convince her father to allow her to marry Minos, suggesting that she herself could seal a peace treaty, making the case that it is worth trying to insert her family into the lineage of Jupiter, praising peace, speaking to the king's counselors, seeking and finding unfavorable omens, and even bribing priests to support her position. These efforts fail, so Carme performs some magical ritual. Nisus, we are told, trusts in his lock of hair and so continues to resist Minos. Finally, having exhausted their other options, the two women decide together that the cutting of the lock is the only choice left to them. The phrasing here is interesting and peculiar, as it is left to Carme's decision (rursus ad inceptum sociam se adiungit alumnae/ purpureumque parat rursus tondere capillum, tam longo quod iam captat succurrere amori ... (381-3). So too, the lengthy delay in the Ciris, in contrast to Scylla's instantaneous move from decision to action in Ovid's version of the story (Ciris 220-385 vs. Met. 8.80-1), implicitly lends a degree of reasonableness to the proceedings in the former. As if this were not enough, Carme is given further responsibility and motivation: she supports shearing the lock (and leaving Megara with Ciris) because she would like to see to her Cretan homeland again before she dies (384-5). Here again the poet of the Ciris is much more interested than Ovid is - at least in this story - in how such decisions get made and who is accountable for them.

18 Finally, at Ciris 386 (that is, about three hundred lines later in this narrative than in Ovid's version), Ciris removes her father's lock of hair. As in the Ovidian version, interestingly, this part is told so briefly as almost not to be told; it is buried in a triple anaphora of line-starting tum, and is voiced in the passive:

Ergo iterum capiti Scylla est inimica paterno:

tum coma Sidonio florens deciditur ostro, 
tum capitur Megara et divum responsa probantur,

tum suspense novo ritu de navibus altis

per mare caeruleum trahitur Niseia virgo. (Ciris 386-90) they pass (459-80). As Ciris grows weary, various sea-monsters close in on her. Finally, Amphitrite takes pity on her and turns her into a bird (481-89). Ciris' metamorphosis occurs with a luxuriant detail in keeping with the poem as a whole, across seventeen lines. This is just the kind of expansion often found elsewhere in the Metamorphoses, but Ovid's own version rushes through Scylla's change in only two lines (Met. 8.150-1), while Nisus' takes a mere line and a half (Met. 8.145-6). 
And that, for Ovid, is that: he transitions to Minos' actions back in Crete. The poet of the Ciris, having emphasized the loneliness of the new bird, then tells us that Jupiter felt that Ciris' punishment did not fit the wickedness of her crime, not least because of Nisus' longstanding piety toward the god (520-6). So Jupiter changes Nisus into a seaeagle (in about a line, 527-8), and makes him pursue his daughter forever. The Ciris ends with an Ovidian kind of just-so moral, explaining that this is the cause of the yearly pursuit of the one bird by the other.

It is difficult not to notice that - although they tell the same basic story - the two versions are rather different. Anecdotally, I have found that most readers find one significantly more satisfying than the other: ${ }^{18}$ perhaps you like the lengthy description of place, the inset tale, and the detailed description of metamorphosis in the Ciris, or perhaps you prefer the more businesslike pace and double monologues of the Metamorphoses version. Importantly, however, Ovid's Metamorphoses contains all of the same elements as the Ciris, in different locales, such that it is probably fruitless to put too much into these individual choices. I reiterate the point that the quasi-Ovidian elements in the Ciris could plausibly be read as similar to what Ovid does with Vergil, wherein the latter poet shows the former to have missed a trick. Or the Ciris might have been one of Ovid's own influences in thinking about metamorphoses.

My minimal hope for this chapter is to have made clear that it is not quite as easy as some think to determine relative priority of poetic texts. There are elements in both narratives that we might very legitimately think of as essential, the kind of thing you would certainly have included unless someone else had beaten you to it. There are also elements we might think of as derivative, the kind of thing you might include only if the good bits had already been taken. And - again - this is to leave out of consideration the quantity of similar stories: there is much we do not know about the immediate predecessors of each poem, and the narrative choices they have made in their heroinetales.

This leads to my larger and more ambitious point, which is to suggest that the process of picking out the good and original from the not-so-good and derivative is itself not terribly useful. Instead, I suggest, each poet is guided, at least in part, by a sense of what is appropriate to his aims in the particular poem. The differences I have outlined in the two narratives could be - indeed, have been - used to make a slightly-better-than plausible case for the priority of either Ovid or of pseudo-Vergil. Some readers will favour one hypothesis over the other, but I am afraid that this is likelier to indicate readerly preferences in narrative than which author actually wrote first.

\section{BIBLIOGRAPHY}

Bömer, Franz. P. Ovidius Naso, Metamorphosen Buch VII-IX. Heidelberg: 1969.

Courtney, Edward. The Fragmentary Latin Poets. Oxford: 1993.

Crump, M. Marjorie. The Epyllion from Theocritus to Ovid. Oxford: 1931. 
Curley, Dan. Tragedy in Ovid: Theater, Metatheater, and the Transformation of a Genre. Cambridge: 2013.

Cusset, Christophe. "L'epyllion hellénistique: une forme poétique en quête d'elle-même. Recherches sur les données métapoétiques de l'epyllion.” Aitia 2016: https:// journals.openedition.org/aitia/1376.

Ehlers, Wilhelm. “Die Ciris und ihr Original.” MH 11 (1954): 65-88.

Forbes Irving, Paul. Metamorphosis in Greek Myth. Oxford: 1990.

Frank, Tenney. “Vergil's Apprenticeship.” CP 15 (1920): 23-38; 103-119.

Haury, Auguste. La Ciris: Poème attribué a Virgile. Bordeaux: 1957.

Helm, Rudolf. Die Pseudo-Virgilische Ciris herausgegeben und erklärt. Heidelberg: 1937.

Hetzner, Udo. Andromeda und Tarpeia. Beiträge zur Klassischen Philologie Heft 8. Meisenheim: 1963.

Hielkema, H. Ciris quod Carmen traditur Vergilii versione Batava commentarioque exegetico instructum, Diss. Utrecht: 1941, XIII.

Hollis, Adrian S. Ovid: Metamorphoses Book VII Edited with an Introduction and Commentary. Oxford: 1970.

Jahn, Paul. "Vergil und die Ciris." Rh.M. 53 (1908): 79-106.

Kaffenberger, H. “Zur Cirisfrage.” Philologus 76 (1920): 139-75.

Kayachev, Boris. Allusion and Allegory: Studies in the Ciris. Berlin: 2016.

Lightfoot, J.L. Parthenius of Nicaea: Extant works edited with introduction and commentary. Oxford: 1999.

Lyne, R.O.A.M. The Ciris: A Poem Attributed to Vergil. Cambridge: 1978.

Lyne, R.O.A.M. “Neoteric Poets.” CQ 28 (1978a): 167-87.

Martini, Edgar. Einleitung zu Ovid. Brünn: 1933.

Munari, Franco. Studi sulla 'Ciris'. Collana del Dipartimento di Science Filologiche e Storiche 8. Florence: 1944; reprinted Trento 1998.

Otis, Brooks. Ovid as an Epic Poet. $2^{\text {nd }}$ ed. Cambridge: 1970.

Pagan, Victoria. "Speaking before Superiors: Orpheus in Vergil and Ovid." In Free Speech in Classical Antiquity, edd. I. Sluiter and R. Rosen. Leiden: 2004: 369-89.

Peirano, Irene. The Rhetoric of the Roman Fake: Latin Pseudepigrapha in Context. Cambridge: 2012. Skutsch, Franz. Aus Vergils Frühzeit. Teil I Darstellung/Exkurse; Teil II Gallus und Vergil. Leipzig: 1901.

Sudhaus, S. "Die Ciris und das Römische Epyllion.” Hermes 42 (1907): 469-504.

Woytek, Erich. Die Ciris im Kontext der Augusteischen Dichtung. Wien: 2018.

\section{NOTES}

1. I am grateful to the organizers of the European launch of the IOS for their very kind invitation, to the Scuola Normale in Pisa for hosting us, and also to the lively audience discussion: John F. 
Miller, Alison Keith, Michael Hendry, Barbara Weiden Boyd, Richard Tarrant, and Megan Drinkwater each contributed to my thinking about this chapter (though none of them should be blamed for it). Thanks too to Antony Augoustakis for the opportunity to collaborate on the Ciris, and to John Marincola for suffering discussion of it, which he has never yet suggested was in the least bit tiresome.

2. Bömer well sums up the problem: "dabei kommt es [...] ganz darauf an, welches Gewicht man den einzelnen Argumenten beizumessen geneigt ist" (1969: 14). Among many entrants into the debate, Hollis is probably the most reasonable: he concludes that the Ciris may well have been written first, or that there is a common source (1970: 33; further thoughts on stylistic differences at 35)

3. E.g. Martini 1933: 32.

4. There is much room for debate about what makes an epyllion, in Greek or Latin, or even whether there is such a thing. For the purposes of convenience, in this chapter I define the (Latin) epyllion, very loosely, as a learned hexametrical poem of a longish length with a subjectmatter that often focuses on mythological love-stories or rapes and which engages in sophisticated narrative structures. See Lyne 1978a for more concrete suggestions about the style and tone found in epyllia and Crump 1931 on the Greek (pre-)history. Cusset 2016 well observes that the term is less helpful during the Hellenistic period in which, indeed, the notion of the epyllion may still have been crystalizing. Latin poets regularly make changes to genres and forms they inherit from Greek predecessors.

5. See, for instance, Skutsch 1901, Sudhaus 1907, Jahn 1908, Frank 1920, Kaffenberger 1920, Helm 1937, Hielkema 1941, Munari 1944, Ehlers 1954, Haury 1957, Lyne 1978, and Woytek 2018.

6. Note, for instance, Hollis' comment that "a famous and successful poetic treatment" of some episode obliges Ovid "to strike out in a different direction," whereupon "he chooses different elements of the story to emphasize, passing quickly over those treated in full by his great predecessor" (1970: xxiii). He anticipates parts of my argument by noting that Ovid does not use "the epyllion-technique of the Ciris, with its concentration on moments of especial pathos" (1970: 35).

7. I eschew treating brief retellings, such as at Aeschylus Choeph. 612-22 and Verg. Ecl. 6; see Ehlers 1954, Hollis 1970: 32-3, Lyne 1978: 5-14, and Forbes-Irving 1990: 226-8 for discussion of previous versions of the myth. Hyginus' prose narrative (198) offers interesting points of comparison and, perhaps, what we might consider the bare-bones plot outline: Nisus' lock of hair, war with Minos, Scylla in love and cutting the lock, Minos' horror and departure, Scylla jumping into the water, Nisus' pursuit and metamorphosis into a bird, Scylla's metamorphosis (into a fish).

8. For extensive discussion of the analogues to Tarpeia, see Hetzner 1963; Hollis offers a similar list of "parallel legends" (1970: 34-5)

9. Hollis 1970 treats the Ciris and its relationship to the Scylla-narrative at 33, 46, passim; see too Otis 1970: 62-5.

10. On the other hand, I would be very sympathetic toward an argument suggesting that the poet's philosophical leanings, outlined in this lengthy prologue, provide a helpful and perhaps a necessary context for understanding his moralizing attitude toward the tale he tells.

11. Again, I observe that this exercise is a somewhat-artificial comparison of two, although n. 7 has already suggested the multiplicity of versions of this story potentially available to a poet.

12. Among the substantial bibliography on tragic influences in the Metamorphoses, Curley 2013 is especially useful, with full treatment of previous discussions.

13. Otis suggests that the dialogue between the two is "clearly Euripidean in inspiration" (1970: 63).

14. Reference to Zmyrna also, of course, either refers us to Ovid or perhaps serves as his inspiration; if Ovid's poem predates the Ciris - or even if it does not, the reference to Zmyrna 
(with perhaps hints of the incestuous relationships of Byblis, Canace, and Phaedra?) normalizes Ciris' behavior by suggesting that she is not nearly as degenerate as these women.

15. Am 1.6.22, Her. 16.215, and AA 1.751, all at line-start.

16. Encouraged by Barbara Weiden Boyd, I have come to suspect that both versions of Scylla's entry into the water are abbreviated here because they are told at greater length elsewhere: one is tempted to suggest contaminatio from the other Scylla, turned into a sea monster by Circe.

17. Which it is remains unclear: the Ciris elides the question of whether Ciris had made some verbal agreement with Minos, but this monologue certainly suggests that there had been one. Ovid, for his part, leaves this issue aside, and similar mythic tales provide no useful information, as they vary widely in this particular.

18. This experiment works better if subjects do not know which is the Ovidian, "good" one and which the inferior anonymous poet's.

\section{ABSTRACTS}

This chapter treats the relationship between the pseudo-Vergilian Ciris and Ovid's Scylla-episode in Book 8 of the Metamorphoses. It does not, however, make any claims about who wrote the Ciris, or even about which text influenced which: studies of Prioritätsbestimmung are legion, dating back for a century, and in large part unconvincing, not least because they disagree about the criteria to be used in determining priority. Instead, I offer a readerly treatment of Ovidian intertextuality vis à vis pseudepigraphic poetry. In particular, I will be exploring the mutually reinforcing gaps in the two narratives. These gaps have usually been seen as clues to which author is derivative; I suggest that they instead offer insights into the different poetic goals of the two authors.

\section{AUTHOR}

\section{LAUREL FULKERSON}

The Florida State University

lfulkerson@fsu.edu 